\title{
Upaya Peningkatan Keaktifan dan Hasil Belajar Matematika Menggunakan Model Pembelajaran TSTS Berbantuan Media Tangram
}

\author{
Dewi Aprilliani ${ }^{1}$, Wasitohadi ${ }^{2}$, Theresia Sri Rahayu ${ }^{3}$ \\ ${ }^{1,2,3}$ Program Studi Pendidikan Sekolah Dasar, Universitas Kristen Satya Wacana, Salatiga, \\ e-mail: 292015059@student.uksw.edu, wasito.hadi@uksw.edu, th.rahayu@gmail.com3
}

\begin{abstract}
ABSTRAK
Rendahnya keaktifan dan hasil belajar siswa kelas IV SD Negeri Dukuh 05 yang menjadi dasar dilakukannya penelitian tindakan kelas (PTK). Tujuan dari penelitian ini untuk mengetahui keaktifan dan hasil belajar matematika menggunakan model pembelajaran kooperatif tipe TSTS (Two Stay Two Stray) berbantuan media tangram. Penelitian ini termasuk penelitian tindakan kelas (PTK) yang berkolaboratif dengan guru kelas dengan menggunakan alur perencanaan, pelaksanaan dan pengamatan serta refleksi. Subjek penelitian ini seluruh siswa kelas IV SD Negeri Dukuh 05 yang berjumlah 21 siswa terdiri dari 9 laki-laki dan 12 perempuan. Metode pengumpulan data menggunakan tes untuk hasil belajar siklus I dan II, kemudian non tes untuk keaktifan belajar siswa. Data yang dianalisis menggunakan teknik analisis kualitatif dan kuantitatif. Hasil penelitian menunjukkan bahwa penerapan model pembelajaran kooperatif tipe TSTS berbantuan media tangram berhasil dalam meningkatkan keaktifan dan hasil belajar siswa. Hal ini dibuktikan dari meningkatnya presentase keaktifan siklus I 65,5\% kriteria cukup aktif menjadi $92 \%$ kriteria sangat aktif pada siklus II. Kemudian presentase ketuntasan hasil belajar pada prasiklus 52\% dari 21 siswa menjadi $71 \%$ dari 21 siswa pada siklus I. Kemudian menjadi $86 \%$ dari 21 siswa pada siklus II. Peningkatan juga terjadi pada kegiatan guru dan siswa dalam penerapan model pembelajaran kooperatif tipe TSTS berbantuan media. Dengan demikian, model pembelajaran kooperatif tipe TSTS berbantuan media tangram dapat meningkatkan keaktifan dan hasil belajar matematika siswa kelas IV SD Negeri Dukuh 05 tahun pelajaran 2018/2019.
\end{abstract}

Kata kunci: TSTS, keaktifan, hasil belajar, media tangram

\begin{abstract}
the basis for conducting classroom action research (CAR). The purpose of this study was to determine the activeness and learning results of mathematics using the cooperative learning model type TSTS (Two Stay Two Stray) assisted by tangram media. this research includes classroom action research (CAR) which collaborates with classroom teachers using the flow of planning, implementation and observation and reflection. The subjects of this study were all fourth grade students of SD Negeri Dukuh 05, totaling 21 students consisting 9 men and 21 women. The method of data collection uses tests for learning results in cycles I and II, then non tests for student learning activeness. Data analysed using qualitative and quantitative analysis techniques. The results of the study showed that the application of the cooperative learning model of the TSTS type assistes by tangram media succeeded in increasing student activity and learning outcomes. This is evindenced by the increase in the active percentage of first cycle of $65,5 \%$, the criteria are quite active to $92 \%$ the criteria are very active in cycle II. Then the percentage of completeness in precycle learning outcomes $52 \%$ from 21 students became $71 \%$ of 21 students in cycle I. Then it became $86 \%$ of 21 students in cycle II. The increase also occurred in the activities of teachers and students in the application of the TSTS type cooperative learning model assisted by the media. thus, the cooperative learning model of the TSTS type assisted by tangram media can increase the activiness and result of mathematics learning in fourth grade students of SD Negeri Dukuh 05 School year 2018/2019
\end{abstract}

Keywords : TSTS, activeness, learning results, tangram media 


\section{Pendahuluan}

Matematika adalah ilmu yang mempelajari tentang bilangan, bentuk-bentuk (geometri) yang dapat diekpresikan dan dioperasikan melalui simbol-simbol dimana memerlukan kecakapan berpikir khususnya berlogika atau mengamati pola dan berpikir logis (Wahyudi dan Siswanti, 2015:23-26).Tujuan matematika menurut Islam \& Wardani (2017:629-639) proses pembelajaran matematika di sekolahan bertujuan agar peserta didik dapat berfikir secara logis, meningkatkan kecakapan berpikir, menganalisis, mengambil keputusan, memecahkan masalah serta menggunakan konsep-konsep matematika. Ada beberapa faktor yang dapat mempengaruhi tercapainya tujuan matematika yang berdampak pada keberhasilan siswa dalam muatan pelajaran matematika. Faktor tersebut berasal dari siswa itu sendiri dan dari guru karena guru berperan penting dalam proses pembelajaran. Berbagai upaya yang dilakukan untuk meningkatkan keaktifan dan hasil belajar matematika telah dilakukan semaksimal mungkin, namun masih terdapat siswa yang kurang aktif yang berakibat pada hasil belajar yang rendah.Pernyataan tersebut diperkuat oleh fakta-fakta yang ditemukan berdasarkan hasil observasi dan wawancara yang dilakukan di SD Negeri Dukuh 05.

Dari hasil observasi pada tanggal 10 September 2018 dan wawancara yang telah dilakukan peneliti pada tanggal 13 September 2018 bahwa siswa masih malu-malu untuk bertanya, kurang percaya diri, kurang fokus saat guru menyampaikan materi dan kurangnya kerjasama baik individu maupun kelompok. Hal ini yang berdampak pada hasil belajar siswa yang rendah. Rendahnya hasil belajar siswa tidak hanya dipengaruhi dari siswa itu sendiri tetapi juga dari guru. Dalam proses pembelajaran guru belum menerapkan pembelajaran berkelompok yang inovatif dan menarik minat siswa, hal ini berakibat banyaknya siswa yang berbicara sendiri dengan teman sebangkunya, serta bermain sendiri. Di sisi lain guru juga sudah menerapkan metode tanya jawab dan penugasan di kelas dengan baik serta kurang memaksimalkan penggunaan media. Selain itu, kurangnya siswa dalam menerapkan soal berbasis pemecahan masalah, kurangnya pemahaman konsep yang berakibat pada sulitnya dalam mengerjakan soal dan menghafalkan rumus. Hal ini yang mengakibatkan hasil belajar siswa rendah dilihat dari nilai ulangan harian pada tabel 1.1 sebagai berikut:.

Tabel 1. Nilai Ulangan Harian Siswa Kelas IV SD Negeri Dukuh 05

\begin{tabular}{ccccc}
\hline No. & Aspek & Frekuensi & Presentase & Kategori \\
\hline 1. & $\leq 68$ & 10 & $47,6 \%$ & Tidak Tuntas \\
2. & $>68$ & 11 & $52,4 \%$ & Tuntas \\
& Jumlah & 21 Siswa & $100 \%$ & \\
\hline
\end{tabular}

Berdasarkan Tabel 1. diperoleh hasil nilai ulangan harian siswa kelas IV SD Negeri Dukuh 05 bahwa 10 dari 21 siswa sudah tuntas atau mencapai kriteria ketuntasan minimal (KKM) sebesar 47,6 \%. Kemudian 11 dari 21 siswa belum tuntas atau belum mencapai kriteria ketuntasan minimal (KKM) sebesar 52,4\%.

Dengan rendahnya hasil belajar siswa kelas IV SDN Dukuh 05, peneliti dan guru menyadari adanya beberapa kekurangan sehingga perlu dilakukannya penelitian tindakan kelas agar keaktifan dan hasil belajar siswa pada pembelajaran matematika dapat meningkat. Model yang cocok untuk meningkatkan keaktifan dan hasil belajar siswa dengan menerapkan model pembelajaran kooperatif, salah satunya kooperatif tipe TSTS (Two Stay Two Stray)Menurut Huda (2011:207) model pembelajaran koopertaif tipe TSTS (Two Stay Two Stray) yang mempunyai tujuan agar siswa dapat saling bekerjasama, bertanggung jawab, saling membantu memecahkan masalah, dan saling mendorong satu sama lain untuk berprestasi kemudian melatih siswa untuk bersosialisasi dengan baik. kemudian menurut Lie (2010:62) TSTS adalah suatu model pembelajaran kooperatif yang memberikan kesempatan kepada kelompok membagi hasil dan informasi kepada kelompok lain. Langkah-langkah pembelajaran menurut Lie (2010) antara lain, persiapan, prestasi guru, kerja kelompok, formalisasi dan evaluasi serta pengahargaan. 
Pembelajaran kooperatif tipe TSTS berbantuan media akan membuat proses pembelajaran di dalam kelas akan menjadi lebih menyenangkan dan perhatian siswa akan terpusat pada pelajaran yang diberikan oleh guru serta membuat suasana kelas menjadi aktif. media menururt Mawardi (2018:31) menyatakan bahwa hakkikatnya sesuatu yang dapat digunakan sebagai sarana untuk menyalurkan pesan dan informasi materi pembelajaran sehingga dalam diri siswa terjadi proses belajar dalam rangka mencapai tujuan. Sementara itu menurut Lailiyah \& Sukartiningsih (2018:151) yang menyatakan bahwa media pembelajaran merupakan alat yang digunakan untuk membantu guru menyampaikan sebuah materi atau informasi pada siswa sehingga dapat lebih mudah dipahami oleh siswa. sejalan dengan Menurut Sudjana dan Rivai dalam Arsyad (2011:24) manfaat media pembelajaran adalah 1) pembelajaran akan lebih menarik perhatian siswa sehingga dapat menumbuhkan motivasi belajar. 2) bahan pembelajaran akan lebih jelas maknanya sehingga dapat lebih dipahami oleh siswa dan memungkinkannya menguasai dan mecapai tujuan pembelajaran. 3) metode mengajar akan lebih bervariasi, tidak semata-mata komunikasi verbal melalui penuturan kata-kata oleh guru, sehingga siswa tidak bosan dan guru tidak kehabisan tenaga, apalagi kalua guru megajar pada setiap jam pelajaran. 4) siswa dapat lebih banyak melakukan kegiatan belajar sebab tidak hanya mendengarkan uraian guru, tetapi juga aktivitas lain seperti mengamati, melakukan mendemostrasikan, memerankan dan lain-lain.

Berdasarkan hal tersebut, pembelajaran dengan model pembelajaran kooperatif tipe TSTS memiliki pengaruh terhadap keaktifan dan hasil belajar siswa. Pembelajaran kooperatif tipe TSTS dipilih karena memiliki kelebihan yaitu Kelebihan dari model pembelajaran TSTS yaitu dapat diterapkan pada semua, kelas/tingkatan, kecenderungan belajar siswa menjadi lebih bermakna, lebih berorientasi pada keaktifan, membantu meningkatkan minat dan prestasi belajar, memberikan kesempatan terhadap peserta didik untuk menentukan konsep sendiri dengan cara memecahkan masalah, memberikan kesempatan kepada siswa untuk mencaiptakan kreatifitas dalam melakukan komunikasi dengan teman sekelompok dan siswa dapat mempelajari pembelajaran yang diberikan melalui model tersebut serta dapat mengambil konteks kehidupan dari pembelajaran (Fatmawati, 2015: 45-47).

Media yang yang digunakan untuk menjadikan menjadi lebih aktif dan menyenangkan maka di dalam proses pembelajaran kooperatif tipe TSTS perlu adanya suatu media, salah satunya yaitu media tangram. Tangram adalah suatu himpunan yang terdiri dari tujuh bangun geomoteri datar yang dapat dipotong dari suatu persegi. (Karim, 2009:1.29). bangun datar tersebut adalah segitiga, persegi, persegi Panjang, jajargenjang, trapezium, belah ketupat dan laying-layang. Dengan media tangram akan dapat meningkatkan apresiasi terhadap bangun datar dan diharapkan mampu menumbuh- kan rasa seni serta siswa dapat mengekplorasi bentuk sesuai yang diinginkan oleh pengguna, dan proses pembelajaran akan lebih menyenangkan jika berlangsung dengan menggunakan media tangram.

Menurut Wahyu $(2018,34-41)$ media pembelajaran tangram ini dapat dijadikan guru dalam menyampaikan konsep materi, sedangkan bagi siswa dapat digunakan sebagai sumber belajarnya untuk menggali informasi mengenai konsep materi secara menyenangkan. Dengan menggunakan media pempelajaran maka proses belajar mengajar akan menyenangkan, selain itu guru akan lebih mudah menyampaiakan materi pembelajaran. Sehingga pada akhirnya aktivitas belajar dan hasil belajar siswa akan meningkat. Berdasarkan pemikiran tersebut maka dilakukan penelitian yang berjudul berjudul "Upaya Peningkatan Kekatifan dan Hasil Belajar Matematika Menggunakan Model Pembelajaran TSTS Berbantuan Media Tangram Kelas IV SD”.

\section{Metode}

Tempat penelitian ini dilaksanakan di SD Negeri Dukuh 05 tepatnya di Jalan Janoko Nomor 08, Kecamatan Sidomukti, Kota Salatiga. Dalam 1 siklus diadakan 3 kali pertemuan . Pada siklus I dilaksanakan mulai tanggal 4, 6, dan 7 Februari 2019, sedangkan perbaikan dilakukan di siklus II dilaksanakan mulai tanggal 11, 13, dan 14 Februari 2019. Penelitian ini 
dilaksanakan dalam rentang waktu semester II (semester genap) tahun pelajaran 2018/2019. Subjek penelitia ini adalah seluruh siswa kelas IV SD Negeri Dukuh 05 Salatiga yang terdiri dari 9 laki-laki dan 12 perempuan.

Penelitian ini menggunakan 3 prosedur menurut Kemmiis and Taggart yaitu perencanaan, pelaksanaan dan observasi serta refleksi. 4 tahapan tersebut akan diterapkan dalam 2 siklus, dimana siklus 1 diadakan 3 pertemuan dan begitu juga dengan siklus 2. Alur menurut Kemmis and Mc. Taggart diterapkan dalam proses pemebelajaran sebagai berikut:

Siklus I

\section{Perencanaan}

Pada tahap ini menentukan $\mathrm{KI}$ dan $\mathrm{Kd}$, kemudian membuar rencana pelasanaan pembelajaran (RPP) dengan proses pembelajaran dengan model pembelajaran kooperatif tipe TSTS berbantuan media tangram, selanjutnya membuat media tangram. Menyiapkan lembar obervasi kegiatan guru dan siswa, kemudian membuat lembar observasi keaktifan belajar siswa. serta meyiapkan soal evaluasi siklus I.

2. Pelaksanaan dan observasi

Pelaksanaan disesuaikan dengan RPP dengan model pembelajaran kooperatif tipe TSTS berbantuan media tangram sebagai berikut. 1) Pertemuan Pertama dan Kedua langkah-langkah yang dilakukan adalah a) Apresepsi, pengelolaan kelas, b) Penjelasan singkat mengenai materi pembelajaran, c)Mengarahkan siswa untuk mencari materi sendiri, d) Pemberian LKS, e) Kegiatan berpindah kelompok dimana dua anggota pergi ke kelompok lainnya untuk mencari informasi kemudian dua anggota yang tinggal bertugas membagi informasi kepada dua anggota kelompok yang datang, f) Kembali kelompok semula, g) Presentasi hasil diskusi dan menanggapi, h) Pemberikan soal latihan dan penghargaan, i) Menyimpulkan materi. Dan 2) Pertemuan Ketiga langkah-langkah yang dilakukan diantaranya: a) Apresepsi dan pengelolaan kelas, b) Tanya jawab mengenai materi pertemuan pertama dan kedua, c) Pemberian soal evaluasi siklus I, d) Menyimpulkan

Observasi dilaksanakan saat berlangsungnya pembelajaran dengan mengamati kegiatan guru, siswa serta keaktifan belajar siswa dalam penerapan model pembelajaran kooperatif tipe TSTS berbantuan media tangram pada pembelajaran matematika.

3. Refleksi

Pada tahap ini menganalisis RPP, menganalisis tes, kelemahan dan kelebihan model pembelajaran serta hambatan-hambatan yang akan di perbaiki di siklus II.

Siklus II

1. Perencanaan

Pada tahap ini menentukan $\mathrm{KI}$ dan $\mathrm{Kd}$, kemudian membuar rencana pelasanaan pembelajaran (RPP) dengan proses pembelajaran dengan model pembelajaran kooperatif tipe TSTS berbantuan media tangram, selanjutnya membuat media tangram. Menyiapkan lembar obervasi kegiatan guru dan siswa, kemudian membuat lembar observasi keaktifan belajar siswa. serta meyiapkan soal evaluasi siklus I.

2. Pelaksanaan dan observasi

Pelaksanaan disesuaikan dengan RPP dengan model pembelajaran kooperatif tipe TSTS berbantuan media tangram sebagai berikut: 1) Pertemuan Pertama dan Kedua, adapun langkah-langkah yang dilakukan: a) Apresepsi, pengelolaan kelas, b) Penjelasan singkat mengenai materi pembelajaran, c) Mengarahkan siswa untuk mencari materi sendiri, d) Pemberian LKS, e) Kegiatan berpindah kelompok dimana dua anggota pergi ke kelompok lainnya untuk mencari informasi kemudian dua anggota yang tinggal bertugas membagi informasi kepada dua anggota kelompok yang datang, f) Kembali kelompok semula, g) Presentasi hasil diskusi dan menanggapi, h) Pemberikan soal latihan dan penghargaan, dan i)Menyimpulkan materi, 2) Pertemuan Ketiga, langkah langkah yang dilakukan yaitu a) Apresepsi dan pengelolaan kelas, b) Tanya jawab mengenai materi pertemuan pertama dan kedua, c) Pemberian soal evaluasi siklus I, d) meyimpulkan

Observasi dilaksanakan saat berlangsungnya pembelajaran dengan mengamati kegiatan guru, siswa serta keaktifan belajar siswa dalam penerapan model pembelajaran kooperatif tipe TSTS berbantuan media tangram pada pembelajaran matematika. 


\section{Refleksi}

Pada tahap ini secara umum sudah terjadi peningkatan yang sudah mencapai presentase ketuntasan sebesar $86 \%$ dan presentase keaktifan sebesar $92 \%$. Dapat disimpulkan bahwa hasi penelitian sudah mencapai indikator keberhasilan.

Metode pengumpulan data untuk memperoleh keaktifan siswa menggunakan non tes dan hasil belajar siswa menggunakan tes. Tes diberikan pada saat pertemuan ketiga berupa tes evaluasi pilihan ganda sejumlah 20 , sedangkan non tes berupa lembar observasi keaktifan belajar siswa, lembar observasi kegiatan guru dan siswa.

Sebelum terjun ke lapangan dilakukan uji validitas, uji reliabilitas dan uji kesukaran soal. Setelah mendapatkan soal yang valid lalu diberikan pada pertemuan ketiga untuk mengukut haisl belajar pada siklus I dan II.

Teknik analisis data yang digunakan adalah teknik analisis data kualitatif dan kuantitaif. Kualitatif menganalisis dalam penerapan model pembelajaran kooperatif tipe TSTS berbantuan media tangram dengan memberikan lembar observasi guru dan siswa serta kekatifan belajar siswa. sedangkan kuantitaif digunakan untuk menganalisis hasil belajar siswa.

\section{Hasil dan Pembahasan}

\section{Siklus I}

Pada pertemuan pertama dan kedua peneliti membuat perencanaan yaitu membuat soal evaluasi siklus I, membuat RPP, membuat lembar observasi kegiatan guru dan siswa, keaktifan belajar siswa dan membuat media tangram. Kemudian dalam pelaksanaanya guru menerapkan model pembelajaran kooperatif tipe TSTS berbantuan media tangram yang dimulai dari kegiatan awal melakukan apresepsi dan mengondisikan siswa, guru menjelaskan sedikit materi pembelajaran dengan membimbing siswa untuk menemukan materinya sendiri. Kemudian siswa dibentuk kelompok dan diberi LKS. Setelah selesai mengerjakan, dua anggota pergi ke kelompok lainnya untuk mencari informasi kemudian dua anggota yang tinggal bertugas membagi informasi kepada dua anggota kelompok yang dating. Setelah itu, kembali kekelompok semula. Selanjutnya perwakilan kelompok presentasi hasil diskusi dan kelompok lain menanggapi. Setelah siswa paham guru memberikan soal latihan dan memberikan penghargaan. Kegiatan terakhir menyimpulkan materi bersama-sama dan diakhiri doa.

Pada tahap observasi terjadi peningkatan pada lembar obervasi kegiatan guru dengan jumlah skor 81 kriteria cukup baik menjadi 88 kriteria baik. pada kegiatan siswa juga sudah mengalami peningkatan dengan jumlah skor 63 kriteria cukup baik, kemudian meningkat menjadi 71 kriteria baik. Rata-rata keaktifan belajar siswa juga mengalami peningkatan yang awalnya $61 \%$ kriteria cukup aktif menjadi $70 \%$ kriteria aktif. Hasil belajar siswa siklus I dapat dilihat pada tabel berikut.

Tabel 2. Hasil Belajar Matematika Siklus I

\begin{tabular}{|c|c|c|c|}
\hline No. & Ketuntasan & Frekuensi & Presentase \\
\hline 1. & Tuntas & 15 & 71 \\
\hline 2. & Tidak Tuntas & 6 & 29 \\
\hline Rata-rata & & & 72 \\
\hline Maksimum & & & 90 \\
\hline Minimum & & & 50 \\
\hline
\end{tabular}

Pada tahap refleksi, siswa sudah mulai aktif menemukan materi sendiri dengan bimbingan guru. Kemudian guru dan siswa sudah melaksanakan pembelajaran dengan penerapan model pembelajaran kooperatif tipe TSTS berbantuan media tangram. Pada saat perpindahan siswa ke kelompok lain, siswa merasa bingung yang menyebabkan kekurangan waktu. Kegiatan pembelajaran kurang kondusif karena siswa belum difokuskan untuk 
memperhatikan kelompok lain presentasi. Dari hasil belajar matematika siklus I belum mencapai indikator keberhasilan yaitu $80 \%$, dikarenakan presentase ketuntasan masi $71 \%$. Sehingga perlu dilakukan penelitian tindakan kelas siklus II.

Siklus II

Pada pertemuan pertama dan kedua peneliti membuat perencanaan yaitu menyiapkan soal evaluasi siklus II, membuat RPP, membuat lembar observasi kegiatan guru dan siswa dan keaktifan belajar siswa dan membuat media tangram. Kemudian dalam pelaksanaanya guru menerapkan model pembelajaran kooperatif tipe TSTS berbantuan media tangram yang dimulai dengan guru melakukan apresepsi dan mengondisikan siswa, guru menjelaskan materi pembelajaran dengan membimbing siswa untuk menemukan materinya sendiri. siswa dibentuk kelompok dan diberi LKS. Setelah selesai mengerjakan, dua anggota pergi ke kelompok lainnya untuk mencari informasi kemudian dua anggota yang tinggal bertugas membagi informasi kepada dua anggota kelompok yang dating. Setelah itu, kembali kekelompok semula. Selanjutnya siswa melakukan presentasi hasil diskusi dan kelompok lain menanggapi. Setelah siswa paham guru mebberikan soal latihan dan memberikan penghargaan. Kegiatan terakhir menyimpulkan materi Bersama-sama dan diakhiri doa.

Pada tahap observasi sudah terjadi peningkatan pada kegiatan guru dengan jumlah skor 107 kriteria sangat baik menjadi 121 kriteria sangat baik. Pada kegiatan siswa terjadi peningkatan dengan jumlah skor 87 kriteria sangat baik menjadi 96 kriteria sangat baik.

Rata-rata keaktifan belajar siswa juga mengalami peningkatan yang awalnya $88 \%$ kriteria sangat aktif menjadi $96 \%$ kriteria sangat aktif. Hasil belajar siswa pada siklus I dapat dilihat pada tabel berikut.

Tabel 3. Hasil Belajar Matematika Siklus II

\begin{tabular}{|c|c|c|c|}
\hline No. & Ketuntasan & Frekuensi & Presentase \\
\hline 1. & Tuntas & 18 & 86 \\
\hline 2. & Tidak Tuntas & 3 & 14 \\
\hline $\begin{array}{l}\text { Rata-rata } \\
\text { Maksimum } \\
\text { Minimum }\end{array}$ & & & \\
\hline
\end{tabular}

Pada tahap refleski siklus II Pada pelaksanaan kegiatan guru dan siswa sudah terjadi peningkatan yang signifikan. Keaktifan siswa juga mengalami peningkatan dari jumlah skor $88 \%$ menjadi $96 \%$ kategori sangat aktif. Selanjutnya Hasil belajar siswa pada siklus I presentase ketuntasan $71 \%$ meningkat menjadi $86 \%$. Hal ini sudah mencapai indikator keberhasilan sehingga tidak diadakan siklus selanjutnya.

Berdasarkan data hasil penelitian yang dilaksanakan di SD Negeri Dukuh 05 bahwa terjadi peningkatan pada kegiatan guru pada siklus I rata-rata skor 84,5 menjadi 114 pada siklus II. Pada kegiatan siswa rata-rata skor pada siklus I 67 meningkat menjadi 91,5 pada siklus II. Presentase keaktifan belajar siswa juga meningkat $65,5 \%$ mejadi $92 \%$ pada siklus II. Peningkatan keaktifan dapat dilihat pada tabel berikut.

Tabel 4. Keaktifan Belajar Siswa Dalam Pembelajaran Matematika

\begin{tabular}{lcc}
\hline \multicolumn{1}{c}{ Keaktifan } & Siklus I & Siklus II \\
\hline Presentase & $65,5 \%$ & $92 \%$ \\
Kriteria & Cukup Aktif & Sangat Aktif \\
\hline
\end{tabular}

Peningkatan keaktifan belajar siswa dapat dilihat pada diagaram berikut. 


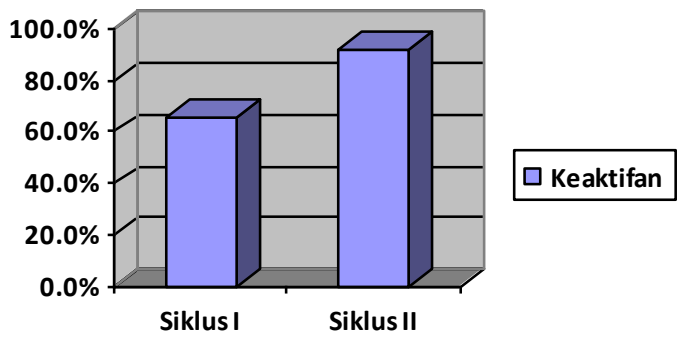

\section{Gambar 1. Peningkatan keaktifan belajar siswa}

Peningkatan keaktifan siswa mempunyai dampak pada hasil belajar pada siklus I dan siklus II denga KKM $\leq 68$. Pada Prasiklus sebanyak 10 siswa atau 52\% mencapai KKM, pada siklus I terjadi peningkatan sebanyak 15 siswa atau $71 \%$ mencapai KKM. Kemudian dari kekurangan siklus I diperbaiki disiklus II menggunakan model pembelajaran kooperatif tipe TSTS berbantuan media tangram dengan hasil belajar yang meningkat. Dari18 siswa atau $86 \%$ mencapai KKM. lebih jelasnya dapat dilihat pada Tabel berikut.

Tabel 5. Ketuntasan Hasil Belajar Matematika Prasiklus, Siklus 1 dan Siklus II

\begin{tabular}{|c|c|c|c|c|c|c|}
\hline \multirow[t]{2}{*}{ Ketuntasan } & \multicolumn{2}{|c|}{ Prasiklus } & \multicolumn{2}{|c|}{ Siklus I } & \multicolumn{2}{|c|}{ Siklus II } \\
\hline & f & $\%$ & $f$ & $\%$ & f & $\%$ \\
\hline Tuntas & 10 & 52 & 15 & 71 & 18 & 86 \\
\hline Tidak Tuntas & 11 & 48 & 6 & 29 & 3 & 14 \\
\hline Rata-Rata & \multicolumn{2}{|c|}{64} & \multicolumn{2}{|c|}{72} & \multicolumn{2}{|c|}{80} \\
\hline Maksimum & \multicolumn{2}{|c|}{80} & \multicolumn{2}{|c|}{90} & \multicolumn{2}{|c|}{100} \\
\hline Minimum & \multicolumn{2}{|c|}{40} & \multicolumn{2}{|c|}{50} & \multicolumn{2}{|c|}{65} \\
\hline
\end{tabular}

Dari ketuntasan hasil belajar matematika pada pembelajaran prasiklus, siklus I dan siklus II peningkatannya dapat dilihat pada diagram berikut.

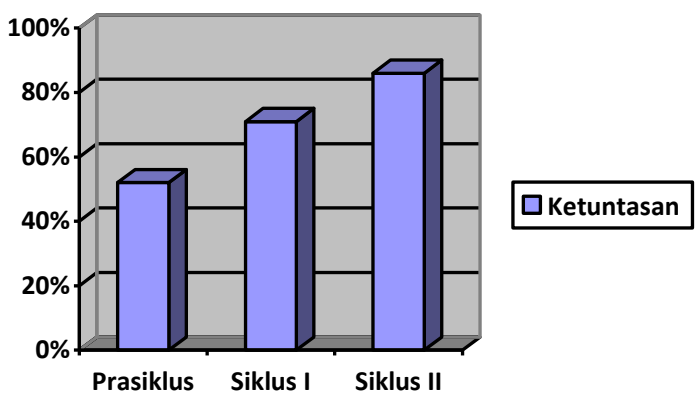

Gambar 2 Peningkatan ketuntasan presentase ketuntasan

Dari hasil penelitian keaktifan belajar siswa dan hasil belajar siswa sudah melebihi indikator keberhasilan, sehingga tidak dilanjutkan kesiklus III. Dalam penerapan model pembelajaran kooperatif tipe TSTS berbantuan media tangram mampu meningkatkan keaktifan dan hasil belajar siswa. Hal ini kelebihan dari model pembelajaran TSTS adalah memberikan kesempatan terhadap kesempatan siswa unuk menentukan konsep sendiri dengan cara memecahkan masalah dengan cara berkomunikasi dengan teman sekelompoknya.

Sehingga tidak hanya siswa bertukar pikiran tetapi juga siswa dapat bersosialisasi. Penggunaan model pembelajaran koopertaif tipe TSTS berbantuan media tangram memberikan dampak positif dalam proses pembelajaran, karena dalam pembelajaran siswa 
lebih aktif, bertanggung jawab, memecahkan persoalan, menemukan konsep sendiri serta belajar berkomunikasi dengan teman lain maupun berkelompok. Hal ini sesuai dengan penelitian Indriyani (2011:189) menunjukkan hasil bahwa model pembelajaran kooperatif teknik Two Stay Two Stray dapat meningkatkan aktivitas guru, dimana pada siklus 1 ratarata 2,8 dan meningkatkan pada siklus II rata-rata menjadi 3,3.

Kemudian dapat meningkatkan aktivitas belajar pada siklus 1 rata-rata 2,85 kemudian meningkatkan pada siklus II rata-rata mejadi 3,22. Model pembelajaran kooperatif tipe Two Stay Two Stray dapat meningkatkan hasil belajar dengan nilai rata-rata siklus I 70 dan 79 pada siklus II. Ketuntasan siklus I adalah $69 \%$ menjadi $82 \%$ pada siklus II dengan KKM 65 dan Menurut Wahyu, A. (2018:34-41) yang berjudul "Penerapan Media Pembelajaran Tangram Untuk Meningkatkan Hasil Belajar Pengenalan Bangun Datar Pada Siswa Kelas I SDN Pesantren Tembeleng Jombang Tahun Ajaran 2016-2017" yang menunjukkan hasil bahwa seluruh aktivitas belajar siswa diantaranya dalam berdiskusi kelompok pada siklus I mencapai $60 \%$ mengalami peningkatan pada siklus II sebesar $80 \%$, mengajukan pertanyaan pada siklus I mencapai $56.7 \%$ mengalami peningkatan pada siklus II sebesar $73.3 \%$, memperhatikan presentasi pada siklus I mencapai $73.3 \%$ mengalami peningkatan pada siklus II sebesar $83.3 \%$, dan tertib selama pembelajaran pada siklus I mencapai $70 \%$ mengalami peningkatan pada siklus II sebesar $83.3 \%$. Sedangkan hasil belajar siswa dapat dilihat dari pencapaian ketuntasan belajar siswa pada sisklus I mencapai 63,6\% dengan nilai rata-rata 65 , dan pada silkus II mengalami peningkatan sebesar $90,9 \%$ dengan nilai rata-rata 85.

\section{Simpulan dan Saran}

Berdasarkan hasil analisis data data disimpulkan bahwa terjadi peningkatan keaktifan siswa dan hasil belajar siswa dalam pembelajaran kooperatif tipe TSTS berbantuan media tangram pada siswa kelas IV SD Negeri Dukuh 05 Semester II Tahun Pelajaran 20182019, dibutkikan dengan hasil sebagai berikut:

Peningkatan keaktifan belajar dalam pembelajaran matematika menggunakan model pembelajaran kooperatif tipe TSTS berbantuan media, dimana pada siklus I mencapai skor 65,5 dengan kriteria cukup aktif. Kurangan yang terdapat pada siklus I diperbaiki di siklus II, sehingga keaktifan belajar siswa meningkat mencapai skor 92 dengan kriteria sangat aktif. Keaktifan belajar siswa yang baik dapat berdampak pada meningkatnya hasil belajar siswa. Peningkatan terjadi juga pada hasil belajar siswa dalam dalam pembelajaran matematika menggunakan model pembelajaran kooperatif tipe TSTS berbantuan media tangram. Sebelum dilakukan tindakan jumlah siswa yang tuntas sebanyak 10 siswa atau $52 \%$ dari jumlah keseluruhan siswa yaitu 21 siswa, kemudian meningkat pada siklus I sebanyak 15 siswa atau $71 \%$ dari jumlah keseluruhan siswa yaitu 21 siswa. Pada siklus II meningkat lagi siswa yang tuntas sebanyak 18 siswa atau $86 \%$ dari jumlah keseluruhan siswa yaitu 21.

Saran yang dapat disampaikan berdasarkan penelitian yang telah dilakukan adalah sebagai berikut; 1) Bagi Sekolahan, sebagai pertimbangan supervisi akademik dan memberikan masukan kepada sekolah untuk meningkatkan mutu sekolah, 2) Bagi Guru dan calon guru, sebagai bahan pertimbangan dalam memilih model pemnbelajaran yang inovatif dalam proses pembelajaran di kelas dan menjadikan salah satu model inovatif unuk mrningkatkan kekatifan dan hasil belajar siswa pada pembelajaran matematika. 3) Bagi Siswa, dan siswa lebih aktif, tidak membosankan, bertukar pikiran dan lebih fokus pada materi serta mencari konsep materi pembelajaran dan membantu dalam pemecahan masalah. Dengan keaktifan siswa yang meningkat mampu berdampak pada meningkatnya pengalaman, pengetahua, ketrampilan serta hasil belajar siswa 


\section{Daftar Pustaka}

Arsyad, Azhar. 2011. Media Pembelajaran. Jakarta:Raja Grafindo Persada.

Fatmawati. D. (2015). Efektivitas Model Pembelajaran Kooperatif Tipe Time Token dan Model Pembelajaran Kooperatif Tipe Two Stay Two Stray Dalam Meningkatkan Ketrampilan Sosial Siswa. Jurnal Bandar Lampung, 45-47.

Huda, M., 2011. Cooperative Learning. Yogyakarta. Pustaka Pelajaran.

Indriyani, C. (2011). Peningkatan Kualitas Pembelajaran IPS Dengan Model Pembelajaran Kooperatif Teknik Two Stay Two Stray Pada Siswa Kelas IV SD Tambakaji 05 Kecamatan Ngaliyan Kota Semarang. Jurnal Kreatif:Jurnal Kependidikan Dasar, 1(2):189.

Islam, Nur M., \& Wardani, Widi K., (2017). Peningkatan Hasil Belajar Matematika Dengan Model Pembelajaran Kooperatif Tipe Two Stay Two Stray Pada Kelas 5. Jurnal Mitra Pendidikan. 1(6):629:639.

Karim. 2009. Pendidikan Matematika. Jakarta: Universitas Terbuka.

Lie, Anita. 2010. Coopertive Learning. Jakarta: Grasindo.

Lailiyah, Nur \& Sukartiningsih, Wahyu. (2018). Pengembangan Media Pembelajaran Interaktif Berbasis Flash Untuk pembelajaran Ketrampilan Menuliskan Kembali Cerita Siswa Kelas IV SD. Jurnal Penelitian Pendidikan Sekolah Dasar. Vol. 6 (7). 23.

Mawardi, M., (2018). Merancang Model dan Media Pembelajaran. Scholaria. Jurnal Pendidikan dan Kebudayaan, 2018. 8 : 26-40.

Wahyudi \& Siswanti, Christy, M., (2015). Pengaruh Pendekatan Saintifik Melalui Model Discovery Learning Dengan Permainan Terhadap Hasil Belajar Matematika Siswa Kelas 5 SD. Scholaria, 5(3):23-36.

Wahyu, A. (2018). Penerapan Media Pembelajaran Tangram Untuk Meningkatkan Hasil Belajar Pengenalan Bangun Datar Pada Siswa Kelas I SDN Pesantren Tembelang Jombang Tahun Ajaran 2016/2017. Edu Math Journal Prodi Pendidikan Matematika, $6(1)$. 